\title{
Teenagers Self-Identity Who Experience Internet Addiction
}

\author{
Novdaly Fillamenta \\ Diploma Program in Medical Record and Health Informatics \\ Widya Dharma, Palembang \\ fillamenta@gmail.com
}

Received: 2 Mac 2018; Accepted: 15 May 2018; Published: 21 December 2018

\begin{abstract}
An Adolescence that called teenager started from the age of 11 or 12 years until the early twenties. The main thing that happens in adolescence is the search for identity. Human identity can occur over the internet where when communication persists between individuals who connect in interaction within it, each individual determines itself as a member of a group, accepts the values of the group, accepts the role of an individual from the group members, as well as determine differences and similarities with group members who included in such interactions.. This study uses descriptive quantitative method that is intended to see how the image of self identity in adolescents who experience internet addiction. Data collection using self-identity scale and internet addiction scale and data analysis using descriptive statistic. Research shows that the majority of subjects are on the status of achievement identity 37 people $(35.19 \%)$, followed by subjects who are on the status of moratorium identity, that is as many as 28 people $(26.85 \%)$, subjects who are in the identity status foreclosure, as many as 22 people $(21.30 \%)$, and subjects who are on the status of diffusion identity that is as many as 18 people $(16.67 \%)$.
\end{abstract}

Keywords: Teenagers, Sef-identity, internet addiction

\section{INTRODUCTION}

Self-identity is a conception of self, the determination of purpose, values, and beliefs held firm by one. Individuals must be able to decide who they are, what their uniqueness is and what their life goals are when they are in their teens (Santrock. 1995). An identity crisis in adolescence will result in identity status (Dariyo, 2004). Identity status is a way used by adolescents to have roles and values that can explain individual identity (Hurlock, 1990). An Identity formation can occur through the internet when communication persists between individuals who engage in interaction within it, each individual determines itself as a member of a group, accepts the values of the group, accepts the role of an individual from the group members, as well as determine differences and similarities with group members who engage in such interactions. The development of internet use becomes a phenomenon which then makes it be a part of human life. This led to various studies that indicate the presence of addiction in the use of the Internet. This study aims to see tennagers self-identity who experience internet addiction.

\section{LITERATURE REVIEW}

\section{Self-Identity}

Individual identity will involve an explanation of who the individual is, what the individual values are, and where the individual chooses to live. Self- identity is a concept of self, the making of a goal, value, 
and belief where for the things that individuals have a commitment. Santrock (2007) suggests that identity is an identity that begins in childhood which then continues in adolescence marked by the question that often arises, namely "Who am I?" Identity in adolescence is often characterized by seeking balance between the need for independence and also the need to connect with others.

An identity information can be described by identity status based on the presence or absence of exploration and commitment (Marcia, 1993). Exploration is a period in which the youth will actively ask, identify, find, dig, and investigate alternatives available to reach a decision on the goals, values, and beliefs to be taken. Teenagers will do the exploration by questioning again, review and explore the various domains of identity. While commitment is loyalty, firmness of founding, principles, and determination to have various possibilities or alternatives chosen. Teenager will make his choice in commited, keep his principles, firm in his stand and not budge on things that can make his or her stance change. Erikson (in Berk, 2007), suggests that the formation of identity can be seen based on the presence or absence of exploration and commitment within the individual. The combination of the presence or absence of crisis and commitment resulted in some of Marcia's opinion about identity (in Berk, 2007).

Individual identity status can be seen when the individual is in the final teenager ie age 18-22 years (Honess \& Yardley, 2005). Marcia (in Berk, 2007) say that there are four types of identity status: difussion, foreclosure, moratorium, achievement. In early adolescence, most teenagers had diffusion identity status, foreclosure, and moratorium (Santrock, 2007). As you get older when you enter your late teens, most individuals are on the status of achievement identity.

\section{Internet addiction}

An Internet addiction has the same meaning as other addictive behaviors, which involves compulsive behavior, lack of interest in other activities, relation to other dependencies, and the presence of physical and mental symptoms that arise when the behavior tries to stop (Essau, 2008). An Individuals who otherwise have been addicted to the internet are individuals who spend much of their time in the interactive functions of the internet and are also involved in various forums available on the internet. Individuals who experience internet addiction can be seen from some of the symptoms that appear. Some of the symptom is like always imagining the activities that can be done in using the internet, feel it takes more time to use the internet so that the time to use the internet longer than the planned time, feel no control to use the internet, feel unable to stop the use of the Internet, the emergence of problems in relationships with others, in work, education or career, and feel useless, guilty, or anxious when not using the internet (Young in Essau, 2008).

Teenagers who experience internet addiction will feel that the satisfaction of using the internet will be obtained when they have more time to use the internet. When an addicted teenager can not use the internet, they will experience symptoms such as withdrawal, anxiety, being angry, anxious, obsessive, behavioral compulsive and also always imagine things related to the internet (Brian \& Wiemer, 2005). According to Griffiths (in Essau, 2008) there are several core components of Internet addiction: salience, mood modification, tolerance, withdrawal symptoms, conflict, and relapse.

\section{Adolescence}

An Adolescence includes mental, emotional, and physical maturity (Hurlock, 1990). An Adolescence is a transitional period of development from childhood to adulthood involving major physical, cognitive, and psychosocial changes (Papalia, 2007). According to Piaget (in Hurlock, 1990) psychologically adolescence is the age that individuals integrate with adult society, the age at which children no longer feel under the level of older people but at the same level, at least in rights issues. An Integration in society (adult) has many aspects of effective, more or less related to puberty. Distinctive intellectual changes also Including to the adolescent way of thinking that can enables adolescents to achieve integration in adult social relationships, which are characteristic of the adolescent developmental period.

According to Hurlock (1990), all developmental tasks during adolescence are focused on overcoming childish behavioral attitudes and patterns and preparing for adulthood. The task of development is related to the identity domain's work,. There are eight characteristics of adolescents declared by Hurlock (1990), namely: adolescence as an important period, transitional period, period of 
change, problem age, identity-seeking, age of fear, unrealistic time, and adolescence as threshold of adulthood. Monks et al (2002) divide the phases of adolescence into three stages: Early adolescents (1215 years), middle-aged (15-18 years), late adolescence (18-21 years).

\section{Teenager and Internet}

The term "adolescence" come from the latin word "adolescer", which means "to grow" or "grow into adulthood". An adolescence period includes mental, emotional and physical maturity (Hurlock, 1990). According to Piaget (in Hurlock, 1990), psychologically adolescence is the age where individual integrate with other society, the age where the children no longer feelt below the level of older people, but be in the same level, at least in the matters of rights. All developmental tasks in adolescence are centered on overcoming childish behavioral attitudes and patterns, and making preparations to deal with adolescence (Hurlock, 1990). The task of development is related to the domain of identity. The identity domain are jobs, ideological beliefs, sexuality beliefs.

In the early years of adolescence, adjustment to the group is still important, over-time teenagers begin to crave self-identity and do not feel satisfied with the similarities they have with friends in every things. The desire to remain the same as the group and also the desire to have a self-identity ultimately leads to a dilemma that creates an "identity crisis" or a problem in the identity of adolescents. This is an accordance with was stated by Erickson (in Hurlock,1990), that self-identity sought by teenagers in the form of an effort to explain who he/she is, what is his/her role in society, whether a child or an adult, can he be a husband or father, can she be a wife or a mother, is he/she able to remain confident despite his/her racial, cultural background, religion or nationality make some people demean him/her, and overall whether he/she will succeed or fail in doing many thing in life.

The use of internet is a very interesting thing for teenagers today. This happens because through the internet teenagers can communicate with other people so that they can gave and received information. Social characteristics that arise in communication that occur in the real world can also arise naturally when there is virtual communication on the internet use, so that it can lead to identity formation (Kuss, D.J. \& Griffths, M.D., 2011).

\section{METHODOLOGY}

This study uses quantitative descriptive method to see teenagers self-identity who experience internet addiction. Implementation of research in sub-district Alang-Alang Lebar, Palembang from April to May 2017. The sample of this study amounted to 105 teenagers who experience internet addiction was taken with incidental sampling technique. The dependent variable in this research is self identity. The Independent variable is internet addiction. Data collection using instruments self-identity scale and internet addiction scale and data analysis using descriptive statistic.

The results of internet addiction scale test shows the reliability of the measured tool is 0.948 . The number of items with discrimination index above 0.300 is 62 items with the value of rxx 'moving from 0.315 to 0.692 . The results of internet addiction scale test shows the reliability of the measured tool is 0.948 . The number of items having discrimination index above 0.300 is 62 items with the value of rxx 'moving from 0.315 to 0.692 . The test results of the self-identity scale are processed by looking at the index of discrimination on options A, B, C, D. In the subject scale, an item will be expressed fails if the four options, (A, B, C, D) have discrimination indexes that are less than 0.300 .

If either option (A, B, C, or D) has a discriminating index> 0.300 then the aitem is valid. In the choice of A measuring tool reliability is tested is 0.894 . The number of items having a discrimination index above 0.300 is 27 items with the value of rxx 'moving from 0.305 to 0.623 . In the choice of B tested tool reliability is 0.860 . The number of items with discrimination index above 0.300 is 20 items with the value of rxx 'moving from 0.344 to 0.588 . In the choice of $\mathrm{C}$ reliability measuring tool that tested is equal to 0.776 . The number of items having discrimination index above 0.300 is 16 items with the value of rxx 'moving from 0.310 to 0.464 . In the choice of D reliability of the measured tool is 0.920 . The number of items having different indexes above 0.300 is 32 items with the value of rxx 'moving from 0.346 to 0.674 . 
The assumption that the subject score in the group is an estimate of the subject score in the population and that the subject scores in the population have been normally distributed must be met before categorization. Data were tested using One Sample Kolmogorov-Smirnov to find out if the data has been normally distributed.

Tabel 1 Test Result Normality of Research Data from Internet Addiction

\begin{tabular}{|l|l|}
\hline & Internet addiction \\
\hline Kolmogorov-Smirnov Z & 0,590 \\
\hline Asymp. Sig. (2-tailed) & 0,878 \\
\hline
\end{tabular}

Based on table 1, obtained the value of $\mathrm{Z}$ amounted to 0.590 and the value of significance (p) of 0.878 . Because of the $p>0,05$, the data in this study is normally distributed, thus the subject of the study can be categorized into three categories based on normal distribution model: high internet addiction, medium internet addiction and low internet addiction. Based on the categorization, the subject that will be used to see the description of identity status in this study is the subject that scores internet addiction scale is in the medium and high category. This is done so that the subject of research really get addicted.

\section{RESULT}

General descriptions of maximum, minimum, mean, and standard teenagers internet addiction deviation scores

Tabel 2 Statistic description internet addiction

\begin{tabular}{|c|c|c|c|c|c|c|}
\hline Variable & Data & N & Min & Maks & Mean & $\begin{array}{c}\text { Standar } \\
\text { Deviation }\end{array}$ \\
\hline $\begin{array}{c}\text { Internet } \\
\text { Addiction }\end{array}$ & Hipotetik & 131 & 62 & 310 & 186 & 31 \\
\cline { 2 - 7 } & Empirik & 131 & 83 & 257 & 162,22 & 35,184 \\
\hline
\end{tabular}

Based on the classification of subjects who experience internet addiction then the subject used in this study is 105 people. The main results of this study is a general picture of identity status in adolescents who experience internet addiction.

Based on the classification of subjects who experience internet addiction then the subject used in this study is 105 people. The main results of this study is a general picture of identity status in adolescents who experience internet addiction. To classify a subject into an existing identity status then use Zscore of each total answer of the four identity states selected by the subject. Subjects will be categorized into one of the identity states that shows the highest Zscore.

Tabel 3 Self-identity teenagers who have internet addiction

\begin{tabular}{|l|l|l|}
\hline Identity Status & Amount of sampels(N) & Persentage \% \\
\hline Diffusion & 18 & 16,67 \\
\hline Foreclosure & 22 & 21,30 \\
\hline Moratorium & 28 & 26,85 \\
\hline Achievement & 37 & 35,19 \\
\hline Total & 105 & 100 \\
\hline
\end{tabular}

the distribution of subjects who have the level of internet addiction that is most at the status of achievement identity that is as many as 30 people (28.70\%), followed by subjects who are on the status 
of moratorium identity as many as 24 people $(23.15 \%)$, the subject is in the status of foreclosure identity of 17 people (16.67\%), and subjects who are in the status of diffusion identity are as many as 14 people (12.96\%).Distribution of subjects who have high internet addiction rate at most are on achievement status of 7 people $(6.48 \%)$, followed by subjects who are on foreclosure identity status that is as much as 5 people $(4.63 \%)$, and the subject is on the identity status of moratorium and diffusion each of 4 people $(3.70 \%)$.

Tabel 4 Self-Identity based on internet addiction level

\begin{tabular}{|l|l|l|l|}
\hline \multirow{2}{*}{$\begin{array}{l}\text { Internet addiction } \\
\text { level }\end{array}$} & Self-identity & $\begin{array}{l}\text { Amount } \\
\text { (Peoples) }\end{array}$ & $\begin{array}{l}\text { Persentage } \\
(\mathbf{\%})\end{array}$ \\
\hline \multirow{5}{*}{ middle } & Diffusion & 14 & 12,96 \\
\cline { 2 - 4 } & Foreclosure & 17 & 16,67 \\
\cline { 2 - 4 } & Moratorium & 24 & 23,15 \\
\cline { 2 - 4 } & Achievement & 30 & 28,70 \\
\hline \multirow{5}{*}{ high } & Diffusion & 4 & 3,70 \\
\cline { 2 - 4 } & Foreclosure & 5 & 4,63 \\
\cline { 2 - 4 } & Moratorium & 4 & 3,70 \\
\cline { 2 - 4 } & Achievement & 7 & 6,48 \\
\hline Total & & $\mathbf{1 0 5}$ & $\mathbf{1 0 0}$ \\
\hline
\end{tabular}

Tabel 5 Teenagers sel-identity based on gender

\begin{tabular}{|l|l|l|l|}
\hline Gender & Self-Identity & Amount (People) & $\begin{array}{l}\text { Persentage } \\
(\mathbf{\%})\end{array}$ \\
\hline \multirow{4}{*}{ Men } & Diffusion & 13 & 12,96 \\
\cline { 2 - 4 } & Foreclosure & 16 & 14,81 \\
\cline { 2 - 4 } & Moratorium & 16 & 14,81 \\
\cline { 2 - 4 } & Achievement & 20 & 19,44 \\
\hline \multirow{5}{*}{ Women } & Diffusion & 4 & 3,70 \\
\cline { 2 - 4 } & Foreclosure & 7 & 6,48 \\
\cline { 2 - 4 } & Moratorium & 13 & 12,04 \\
\cline { 2 - 4 } & Achievement & 16 & 15,74 \\
\hline Total & & $\mathbf{1 0 5}$ & $\mathbf{1 0 0}$ \\
\hline
\end{tabular}

Based gender, the subjects of both men and women were at most on the status of achievement identity, which were 21 men $(19.44 \%)$ and $17(15.74 \%)$ women.

Tabel 6 Tennager Self-Identity based on application internet

\begin{tabular}{|l|l|l|l|}
\hline Internet aplication & Self-identity & $\begin{array}{l}\text { Amount } \\
\text { (People) }\end{array}$ & $\begin{array}{l}\text { Persentage } \\
(\%)\end{array}$ \\
\hline \multirow{2}{*}{$\begin{array}{l}\text { Chat Rooms } \\
\text { (Whatsapp, Line, } \\
\text { BBM) }\end{array}$} & Diffusion & - & - \\
\cline { 2 - 4 } & Foreclosure & - & - \\
\cline { 2 - 4 } & Moratorium & 1 & 0,93 \\
\cline { 2 - 4 } & Achievement & 1 & 0,93 \\
\hline \multirow{5}{*}{ Game Online } & Diffusion & 10 & 9,26 \\
\cline { 2 - 4 } & Foreclosure & 9 & 8,33 \\
\cline { 2 - 4 } & Moratorium & 9 & 8,33 \\
\cline { 2 - 4 } & Achievement & 4 & 4,63 \\
\hline E-mail (Yahoo mail, & Diffusion & 1 & 0,93 \\
\hline
\end{tabular}




\begin{tabular}{|l|l|l|l|}
\hline \multirow{4}{*}{ G-mail, Hotmail) } & Foreclosure & 1 & 0,93 \\
\cline { 2 - 4 } & Moratorium & - & - \\
\cline { 2 - 4 } & Achievement & - & - \\
\hline \multirow{2}{*}{$\begin{array}{l}\text { Website (Facebook, } \\
\text { YouTube, Twitter, }\end{array}$} & Diffusion & 5 & 4,63 \\
\cline { 2 - 4 } & Foreclosure & 9 & 8,33 \\
\cline { 2 - 4 } & Moratorium & 14 & 13,89 \\
\cline { 2 - 4 } & Achievement & 26 & 22,22 \\
\hline \multirow{3}{*}{$\begin{array}{l}\text { Web Search (Yahoo, } \\
\text { Google) }\end{array}$} & Diffusion & 2 & 1,85 \\
\cline { 2 - 4 } & Foreclosure & 4 & 3,70 \\
\cline { 2 - 4 } & Moratorium & 4 & 3,70 \\
\cline { 2 - 4 } & Achievement & 5 & $\mathbf{1 0 0}$ \\
\hline \multirow{2}{*}{ Total } & & $\mathbf{1 0 5}$ & \\
\hline
\end{tabular}

Based on internet application most are on the status of achievement identity, that is as much as 26 people $(22.22 \%)$ subject of website users and 5 people (4.63\%) subject of websearch users, while subjects using online gaming applications at most are on the status of diffusion identity as many as 10 people $(9.26 \%)$.

\section{CONCLUSION}

Self-Identity was affected by Intensity of excessive Internet usage that can cause internet addiction. Identity achievement 37 subjetcs (35.19\%), 28 subjectsidentity of the moratorium (26.85\%), 22 subjects $(21.30 \%)$ who are on foreclosure identity status. diffusion identity status 18 subjects (16.67\%).

\section{REFERENCES}

Berk, Laura E. (2007). Development through the lifespan. United State of America: Pearson Education. Brian \& Wiemer. (2005). Addiction to the internet and online gaming. Journal of Cyberpsychology \& Behavior, 8 (2).

Dariyo, Agoes. (2004). Psikologi perkembangan remaja. Bogor: Penerbit Ghalia Indonesia.

Essau, Cecilia A. (2008). Adolescent addiction: Epidemiology, assessment and treatment. New York: Elsevier Inc.

Hurlock, Elizabeth H. (1990). Psikologi perkembangan: Suatu pendekatan sepanjang rentang kehidupan. Jakarta: Penerbit Erlangga.

Kuss, D.J. \& Griffths, M.D. (2011). Online Social Networking and addiction - a review of psychological literature. International Journal of Environmental Research and Public Helath, 8.

Papalia, D.E., Olds. S.W., \& Feldman R. D. (2007). Human Development. 10th ed. New York: McGraw Hill.

Pickhardt,Carl E. (2016, May 26). Adolescence and internet identity. Retrieved from https://www.psychologytoday.com/blog/surviving-your-childs-adolescence/201405/adolescence-andinternet-identity

Santrock, John W. (1995). Life-Span Development, 5E. Dallas: University of Texas.

Witmer, D. (2017, March 27). Teen and teenager definition for parents from child to young adult: The teen years are a time of transition. Retrieved from https://www.verywellfamily.com/teen-teenager-2608827 